\title{
A ordem urbana religiosa no Rio de Janeiro colonial
}

Fania Fridman ${ }^{1}$

Valter L. Macedo ${ }^{2}$

O desenho urbano, quando analisado em sua gênese, reflete os processos de acumulação e de parcelamento dos patrimônios territoriais verificados ao longo do tempo. Neste contexto, ordens religiosas e irmandades, através de seus patrimônios imobiliário e fundiário desempenharam, de uma forma geral e no caso específico do Rio de Janeiro, importante papel no processo de conformação do chão da cidade, desde sua fundação (1565) até a promulgação da Lei de Terras no Brasil (1850).

Em relação ao período colonial, consideramos que a paisagem urbana estava vinculada à presença dos religiosos, uma vez que cada ordem, irmandade ou confraria dominava uma parcela do território, sendo esta dominação de base econômica - a produção agrícola, pastoril e de serviços, além do acúmulo de propriedades imobiliárias - e ideológica, exercida pela religião católica. Este texto analisa o papel desempenhado pela Igreja na produção do espaço e suas conseqüências sobre o cotidiano na cidade do Rio de Janeiro.

\section{Patrimônio e poder}

Ao projeto português expansionista, de enriquecimento da Metrópole, estava atrelada a propagação da fé cristã em uma cruzada santa anti-pagã e anti-protestante. A união EstadoIgreja garantiu a presença constante e numerosa de religiosos, com suas igrejas e ideais, em todas as colônias portuguesas. No Rio de Janeiro, estavam desde a fundação.

A igreja no Brasil colonial contava, segundo Hoonaert (1982), com a presença das ordens religiosas e das confrarias. Estas eram de dois tipos: as ordens terceiras e as irmandades. As ordens terceiras vinculavam-se às tradições religiosas e relacionavam-se aos franciscanos, aos carmelitas e aos dominicanos. As irmandades, uma herança da Idade Média, representavam as antigas corporações de ofício em um momento histórico onde inexistiam

\footnotetext{
${ }^{1}$ Professora do IPPUR/UFRJ e coordenadora do Grupo de Estudos do Território e de História Urbana (GESTHU /IPPUR/UFRJ).

${ }^{2}$ Professor do CBNB/III COMAR, doutorando do IPPUR/UFRJ e pesquisador do GESTHU.
} 
partidos políticos ou sindicatos. Além de associações voluntárias de leigos dedicados à beneficência social e à ajuda mútua, para Torres (1968) representavam entidades de classes. ${ }^{3}$

Desde o início da colonização portuguesa houve, no Brasil, irmandades separadas para brancos, índios, negros e, com o aumento da miscigenação, confrarias para os pardos. Isso demonstra uma segregação racial e o exclusivismo social das irmandades no Brasil. De acordo com Silva (1994), as autoridades religiosas apoiavam-nas na tentativa de integrar e cooptar a população à sociedade portuguesa. As associações religiosas leigas desempenharam um importante papel para os escravos ao oferecer empréstimos para a compra da alforria e ajuda nos processos judiciais contra os seus senhores além do direito de sepultamento e de realização das festas religiosas.

Sob o pressuposto da manutenção de suas atividades, as ordens religiosas acumularam, de acordo com o seu prestígio, terrenos e prédios urbanos, além de engenhos, fazendas de gado, olarias, estaleiros, armazéns e hortas. Este acúmulo da propriedade da terra desde o início da colonização deve-se ao fato de que na monarquia portuguesa, a partir dos séculos XI e XII, os direitos da Coroa eram confundidos com os da Igreja. A Ordem de Cristo, que tinha o direito de receber o dízimo eclesiástico de todos os produtos da terra, o dízimo de Deus, era responsável pela administração e a jurisdição espiritual nas terras conquistadas por Portugal. A bula de Julio III de 1550 (Avelar, 1970) incorporou perpetuamente à Coroa o GrãoMestrado de Ordem de Cristo, acrescido das Ordens de Santiago e São Bento de Avis.

O dízimo cobrado pela Coroa era condição para propagar a fé, construir igrejas, pagar as despesas do culto religioso e sustentar os eclesiásticos seculares através da côngrua, remuneração que deveria ser suficiente para a sobrevivência. Entretanto o sustento de uma ordem religiosa dependia também de sua fábrica, isto é, do organismo que administrava o patrimônio e os rendimentos de uma paróquia e zelava pela conservação de seus bens móveis e imóveis. Os jesuítas eram financiados pela Coroa enquanto as demais ordens dependiam de sua fábrica e de ordinárias, auxílios para compra de hóstias, vinho e combustível para lâmpadas das missas.

Por outro lado, o poderio da Igreja em tempos coloniais fica evidenciado também em seu aspecto econômico. Driblando as determinações do Padroado e favorecidas por leis que

\footnotetext{
3 Os Regimentos ou Compromissos das irmandades derivaram daqueles das corporações de ofício onde, pelo menos aparentemente, o caráter de distinção de classes entre mestres e oficiais não se colocava por constituírem grupos com finalidades religiosas. O Compromisso só entrava em vigor depois de examinado pelo Procurador da Coroa e aprovado pelo Rei. O ofício era também denominado bandeira porque seus membros participavam de
} 
autorizavam doações de fiéis, as instituições religiosas constituíram para si consideráveis patrimônios em forma de prédios e terras. As ordens mais importantes chegaram a possuir engenhos, fazendas de gado, olarias, estaleiros, armazéns e hortas, além de um número muito grande de imóveis urbanos. Ao explicar tal processo, Souza (1986) diz que:

Para a maioria esmagadora dos habitantes da colônia, as doenças, as forças e armadilhas da Natureza apresentavam-se como indomáveis, irredutíveis. A fé mostrava, por isso mesmo, contornos tradicionais, arcaicos, onde a demanda de bens materiais e de vantagens concretas assumia grande importância, como se fosse uma espécie de contrato do tipo toma lá-dá cá. (Souza, 1986: 109)

Com o crescimento do patrimônio religioso, a Coroa intensificou a cobrança dos dízimos eclesiásticos a todas as ordens. Até então elas estavam isentas de pagar aqueles referentes aos bens patrimoniais doados, aos frutos de suas hortas, ao gado e às terras nãocultivadas. Entretanto, o poder da Igreja atingia a colônia em todos os níveis ao funcionar como instrumento de controle social. E essa ação encontrava eco no fato de que a condição social do indivíduo implicava, de maneira necessária, no "ser cristão". Desta forma, a obediência aos preceitos religiosos era conseguida através de medidas como a excomunhão e a exposição dos pecadores para a reprovação pública, o que garantia a congregação da população em torno das normas ditadas pela igreja. Com efeito,

É claro que em meio a tanta calamidade existente no período colonial onde muitas doenças eram desconhecidas, e se lutava para conquistar um lugar ao sol, o ser excomungado era sinônimo de estar marginalizado da sociedade que vivia imbuída do espírito da cristandade. (Mira, 1983: 122)

Aos habitantes brancos da colônia, esta era a lei. No entanto, para os negros, todos na condição de infiéis, evidenciava-se uma exclusão ameaçadora. Se, a princípio, os escravos sequer eram considerados em qualquer questão de cunho religioso, não foi sem propósito que não tardaria para que lhes fosse imposto o "direito" de serem católicos. Portanto, a permissão para que a população negra se associasse em irmandades não passou de uma medida política, por parte do Estado português, visando o controle do território e da população.

A variedade de confrarias foi mantida através dos Compromissos que, além de estabelecerem todas as regras de funcionamento, serviram para perpetuar tal segregação, ofícios pela matéria trabalhada ou pelos instrumentos utilizados (Cunha, 1978). 
caracterizando o que Silva (1994) denomina de "exclusivismo social" das irmandades do Brasil. Com efeito:

Art. 20: A Irmandade será sempre composta de pessoas legitimamente pardas e brancas, de ambos os sexos, as primeiras que sejam livres, e todos que sejam verdadeiramente católicos romanos, e bem morigerados, tendo sempre esta Irmandade em eterna memória a primeira base de sua instituição. (Biblioteca Nacional, códice 040 L732.5s)

Observemos o rebatimento, no ambiente urbano, das questões trazidas até aqui para, analisarmos em seguida o caso do Rio de Janeiro.

\section{A ordem urbana}

As Ordenações do Reino provinham da alta Idade Média, portanto de inspiração feudal. As cidades, ao serem fundadas, tinham seu termo e rossio demarcados (Fridman, 1999). O termo, onde se estabeleciam as instituições e as residências, media seis léguas em quadra para cada lado, fixadas a partir do pelourinho, centro que simbolizava a autonomia municipal. O termo era doado em sesmarias ou em datas a quem o requeresse. $\mathrm{O}$ rossio era uma reserva de expansão e utilizado pela população na extração de lenha e de madeira para a construção, como pasto e como terra de plantio. Eram terras livres, áreas destinadas ao uso público no interior do termo. A sua gestão era empreendida pelos vereadores, os "homens bons". A Carta Régia de 6 de dezembro de 1678 permitiu que nas vilas litorâneas os mangues fossem utilizados como combustível para os engenhos à beira-mar e os pobres dali retirassem seu alimento, a despeito da oposição dos padres da Companhia de Jesus e dos beneditinos (Vieira Fazenda, 1923).

A imbricação entre a Igreja e o Estado acarretou formas espaciais específicas para as nossas cidades, distintas das íbero-americanas. Além de propagar a fé, os religiosos exerciam um importante papel político, social, normativo e institucional. O Concílio de Trento (1545 a 1563) e as Constituições Primeiras do Arcebispado da Bahia (publicadas em 1719) regeram em âmbito variado a vida religiosa e mundana brasileira. As Constituições recomendavam que as construções sagradas estivessem em lugares decentes, em sítios altos e livres de umidade. Caso já houvesse ocupação na vila, as igrejas deveriam se instalar onde pudessem passar as procissões. Outra recomendação dizia respeito ao adro - área livre em frente da igreja, praticamente uma piazza - que poderia tornar-se refúgio para os foragidos. 
M. Marx (1991) apontou para a importância da relação Estado/Igreja, negligenciada nos estudos sobre o espaço urbano brasileiro. Segundo o autor, o clero sempre impôs recomendações expressas que interferiram no desenho urbano, ao contrário do que ocorria com as Ordenações, genéricas ou pouco explícitas no que diz respeito à edilidade. Os assentamentos coloniais expressaram essas determinações eclesiásticas principalmente quando a aglomeração surgia espontaneamente. O Rio de Janeiro, apesar de ter nascido cidade - por fundação real - corrobora este aspecto.

Do ponto de vista urbano, as ordens religiosas tiveram um papel importante. Abriram ruas em troca de terras, forneceram água em suas carroças para a população nas invasões estrangeiras, ofereceram bois ao Governador para alimento de residentes de sua casa e de sua comitiva, foram responsáveis pela educação, pela saúde, pela hospedagem dos romeiros pobres nos hospícios e o adro das igrejas acolhia os fugitivos por estar acima das leis seculares. As ordens religiosas possuíram engenhos, fazendas de gado, olarias, estaleiros, armazéns e propriedades. Além disso, seu patrimônio fundiário e imobiliário, acumulado através de doações de famílias nobres e da Coroa, como também por compra, induziu os caminhos da expansão da cidade.

Neste contexto, estas instituições desempenharam importante papel tanto no processo mais geral de ocupação do território brasileiro quanto, mais especificamente, na conformação do "chão" de suas cidades. Através do estudo do Rio de Janeiro, podemos observar que, de fato, tal patrimônio influenciou o processo de expansão e adensamento urbanos sob o julgo de uma Igreja que funcionava como instrumento de controle social.

Da mesma maneira, as irmandades de leigos acumularam bens imóveis. Também entre elas, diferenças puderam ser evidenciadas: às primeiras irmandades instituídas na cidade, congregadoras da população branca e rica, opuseram-se aquelas destinadas aos negros e pobres. E esta oposição foi marcada tanto pelas formas de inserção social quanto pela localização de seus patrimônios. Mais: A escravidão foi, sem dúvida, o elemento primordial na estruturação da sociedade colonial brasileira, pois determinou sua essência ao definir o caráter que as relações sociais assumiram na sua articulação com o processo produtivo adotado. No atendimento aos interesses de uma crescente burguesia mercantil portuguesa, o escravismo colonial à ela foi subordinado e, para este fim, estruturado. 


\section{O exemplo Rio de Janeiro}

Independente de suas ramificações, é importante observar que, a esse tempo, na ausência de outras formas permitidas de lazer, a igreja constituía-se em local para a congregação entre os irmãos e para a busca de informações. No dia-a-dia, eram os badalos dos sinos dos templos que marcavam as horas que orientavam todos os afazeres da população. Às casas religiosas, cabiam também a guarda das economias daqueles mais abastados, o monopólio dos enterros dos brancos da sociedade (uma vez que aos negros só foi concebido enterro católico a partir do século XVIII), a responsabilidade sobre a educação elementar na colônia, bem como todos os serviços hospitalares disponíveis. O clero, diretamente relacionado com o governo, era também a instituição que realizava, através de seus "livros de notas", funções administrativas como registros de nascimentos, casamentos e óbitos, de testamentos e de posses de terras.

Decorrente de seu elevado grau de instrução, eram donos de conhecimentos específicos de vários ofícios, os religiosos das principais ordens também definiam-se como os principais agentes ofertadores de serviços básicos como moradia (tanto pelo aluguel de seus prédios quanto pela própria construção das casas, através do material produzido em suas olarias) e alimentação (bens provenientes de suas hortas e fazendas de gado).

Os jesuítas, carmelitas, franciscanos, beneditinos e capuchinhos chegaram no Rio de Janeiro ainda no século XVI. Os jesuítas, inclusive, acompanharam a fundação da cidade, enquanto as demais ordens e irmandades nela se estabeleceram nas primeiras décadas.

Beneditinos e jesuítas localizavam-se nos morros, e somente os franciscanos, que pertenciam a uma ordem mendicante, encontravam-se fora da área urbana. Os carmelitas distinguiram-se das demais por escolherem o sítio de frente ao porto. As ordens terceiras e irmandades que representavam a elite, como a do Carmo, da Santíssimo Sacramento da freguesia da Candelária (constituída em 1634 pelos ricos entre os quais muitos comerciantes), da Misericórdia, a Militar de Santa Vera Cruz (dos oficiais e soldados da guarnição) e a de São Pedro Gonçalves (dos comerciantes e navegantes), estabeleceram-se intramuros, perto do porto ou nos topos dos morros. A do Santíssimo Sacramento, uma das mais antigas da cidade (de 1567 ou 1569), ficava na Sé. Aquelas dos peões, como a irmandade do Glorioso Patriarca São José (dos oficiais pedreiros, carpinteiros, ladrilheiros, canteiros, violeiros e marceneiros), e a capela da irmandade de Nossa Senhora do Parto (dos carpinteiros pardos) também encontravam-se no núcleo. As irmandades dos mais pobres, como a de São Francisco (dos mulatos) e seu cemitério, instalaram-se no rossio. A primeira irmandade dos escravos, a de 
Nossa Senhora do Rosário, foi fundada antes de 1639 e, em 1667, uniu-se com a confraria de São Benedito. Ambas tinham um altar na Sé. ${ }^{4}$

Quanto à questão do poder, a Câmara Municipal (também denominada de Senado da Câmara) era formada por quatro vereadores ("homens-bons" eleitos ou nomeados entre os proprietários de terras e/ou de escravos e os padres, com um mandato de três anos), um procurador, dois almotacéis (fiscais ou inspetores de pesos e medidas), um tesoureiro e um escrivão. Durante muito tempo, teve razoável autonomia até receber, com o advento do ouro, um juiz ordinário (ou juiz-de-fora) nomeado pela Coroa. Os comerciantes portugueses, com influência crescente por conta de suas atividades na colônia, também conquistaram papel importante na sociedade local, rompendo com o monopólio senhorial e conseguindo assento na Câmara.

Proprietários particulares, ordens religiosas e comerciantes detinham o poder de decisão sobre os acontecimentos, sendo responsáveis por suas principais transformações. Assim, a cidade se estruturava pela ação desses agentes e, sobre este aspecto, um bom exemplo nos é dado por Boxer (1992) ao analisar a Santa Casa da Misericórdia e a Câmara como "pilares gêmeos" da sociedade colonial. Segundo o autor, as relações entre ambas:

[...] garantiam uma continuidade que governadores, bispos e magistrados passageiros não podiam assegurar. (...) A Misericórdia, tal como as irmandades religiosas exclusivas para brancos, eram, de um modo geral, se bem que não invariavelmente, defensora acérrima da superioridade étnica da raça branca e das distinções classistas, exatamente como as Câmaras, com quem estavam tão estritamente ligadas. (Boxer, 1992: 28)

De uma forma geral, destas relações e da ação dos padres, originou-se a produção dos elementos constitutivos da vida diária da população carioca em todo o período que se estabeleceu desde a fundação da cidade até a promulgação da Lei de Terras, em 1850. Em relação aos serviços mais elementares a serem oferecidos aos habitantes, desempenharam papel importante na organização de atividades hoje (ainda) demandadas pelo poder público: educação, habitação, cultura e lazer, saúde e ainda melhorias urbanas. Também foi, por muito

\footnotetext{
4 Como em 1684 a confraria não apresentou seus títulos, o Compromisso e a relação de alfaias, o Cabido ordenou a interdição da capela. Mesmo ao regularizar sua situação, as autoridades não permitiram a prática de nenhum ato sem permissão prévia. Nas reuniões da irmandade havia a presença de um cônego e ainda, a nomeação do capelão, a música das festas e os pregadores dependiam da aprovação do Cabido (Costa, 1886). Em 1693 a irmandade do Rosário comprou uma morada de casas térreas na rua de Dona Marta avaliadas por 96 mil réis (IPHAN - pastas de inventário). Os irmãos do Rosário foram obrigados a sair da Igreja de São Sebastião em 1703 quando iniciaram a edificação de sua igreja, pronta em 1737.
} 
tempo, responsável pelo fornecimento de água e de gêneros alimentícios, bem como por formas de previdência e de assistencialismo.

A função específica de ensino conferida aos jesuítas, por exemplo, se manifestava em seus colégios (como o do morro do Castelo), casas (que funcionavam como centro de moradia e ensino elementar para leigos) e noviciatos (centros de preparação religiosa). Desta forma, segundo Silva Telles (1992), puderam desenvolver sistematicamente seu projeto pedagógico e catequético ao imprimirem nas mentalidades da colônia suas convicções. No caso do Rio de Janeiro, foi a biblioteca dos padres a primeira livraria pública da cidade (Vieira Fazenda, 1921).

Silva Telles (1992) ainda nos fala que foram os padres agentes ativos na construção de grande parte das edificações públicas e, sobretudo, dos fortes aqui erguidos. Sabe-se que eram os índios vindos das aldeias jesuíticas o contigente de mão-de-obra utilizada nessas construções. E os religiosos ainda participavam com recomendações quanto aos seus projetos e até na assistência direta aos "operários" no que diz respeito aos custos com medicamentos e refeições diárias.

Quanto à habitação, era das olarias, pedreiras e fazendas dos religiosos, que vinham os materiais necessários à construção das casas residenciais. Beneditinos, jesuítas e irmãos da Misericórdia, neste sentido, sempre se destacaram como produtores do serviço moradia no Rio de Janeiro também pelo grande volume de imóveis que possuíam, controlando seu acesso através dos aluguéis.

As atividades da Igreja e sua influência ideológica determinaram também o cotidiano cultural e de lazer da cidade. Eram através dos padres, e de seus temas religiosos, as únicas manifestações existentes em relação às teatralizações, artes plásticas ou música. Eram estes referenciais artísticos que faziam parte da vida dos habitantes cariocas. Além do mais, exceto nas datas comemorativas do calendário cívico português, as grandes oportunidades de festas públicas eram oferecidas por ocasião das procissões religiosas ou solenidades (pomposas) decorrentes dos enterros.

De acordo com Schubert (1948), as procissões tradicionais no Rio de Janeiro, conhecidas como "as del Rey" estavam prescritas nas Ordenações do Reino sendo custeadas pelo Senado da Câmara. Eram elas: São Sebastião (comemorada em mar e em terra, teatralizava a fundação da cidade) e Corpo de Deus (com cerimônia final nas esquinas das 
ruas Direita e Alfândega). Sobre a primeira, evidenciando prestígios da época, descreve o autor:

Saiam-se várias fragatas do local da fundação da cidade (morro Cara de Cão), - uma delas com o governador, o visitador dos jesuítas e os principais da terra - passava-se pela baía (praia de Botafogo) e desembarcava-se nas proximidades da Misericórdia. Depois, procissão até a igreja da Misericórdia e, em seguida, para a igreja do morro do Castelo. (Schubert, 1948: 62)

Quanto à oferta de serviços de saúde, previdência e assistencialismo, cabia também aos religiosos o seu cumprimento. Segundo carta régia, ficava determinado à Santa Casa, por exemplo, a cura dos enfermos, o amparo aos pobres, condenados ou enjeitados, as esmolas aos necessitados, o ensino e a proteção aos órfãos, os "dotes às donzelas sem recursos" e a exclusividade sobre o sepultamento. Para isso, a irmandade contava com seu hospital, casas de recolhimento e o cemitério em terreno anexo (para o enterro dos brancos não sepultados nas igrejas a que eram associados). Por outro lado, outras instituições religiosas também ofereciam medicamentos e serviços médicos à população através de suas boticas. E era comum entre as ordens e irmandades, a garantia de condições de vida para as viúvas e filhos de seus irmãos falecidos.

A estruturação do espaço urbano carioca até este período, mesmo que lenta, se mantinha também determinada pela ação principal dos religiosos. Sua presença estava associada à construção de pontes e guindastes (como o do morro do Castelo, ligando a Sé e Colégio dos jesuítas à varzea da cidade), chafarizes, poços e fontes (únicas formas para o abastecimento de água da população), saneamento e aberturas de ruas. As primeiras obras de saneamento no Rio de Janeiro, foram realizadas nas fazendas dos religiosos (jesuítas e beneditinos) e depois trazidas para a cidade.

É relevante também observar que foram os padres (principalmente beneditinos e capuchinhos), conjuntamente com os moradores proprietários do Rio de Janeiro, os responsáveis pela abertura da maior parte das ruas e vias da cidade. Estas obras se davam movidas pelos interesses de seus executantes no sentido de viabilizar a circulação e comunicação entre pontos internos da capital e os diversos estabelecimentos localizados nas proximidades. Por conseguinte, as obras de calçamento também estavam condicionadas a esses agentes. Sobre a ladeira da Misericórdia (primitivo caminho até o alto do morro do Castelo), sabemos que: 


\section{[...] foi a primeira via pública delineada da cidade e primeira rua dotada}

de calçamento de pedras irregulares, executado em 1617, com a contribuição dos seus moradores, por iniciativa dos jesuítas e administrador eclesiástico. (Coaracy, 1988: 351)

Um outro aspecto do cotidiano da cidade e de sua estruturação diz respeito ao fato de que, até o final do século XVIII, o Rio de Janeiro era iluminado apenas nas proximidades dos edifícios religiosos. Para o ano de 1790, há registros de que a iluminação era feita por setenta e três lampiões com óleo de peixe, colocados nas esquinas, em frente às igrejas e nos oratórios espalhados pela pequena cidade (Facó, 1997). O único movimento noturno considerável, naqueles tempos, era o decorrente das ocasiões de festas sacras que se prolongavam depois do escurecer. No mais, além dos "proibidos", apenas escravos, muitas vezes em direção à vala para descarregar tonéis de excrementos provenientes das residências de seus senhores.

Cabe lembrar também que todos os acontecimentos da cidade eram, de certa forma, noticiados no âmbito dos próprios templos (seja no seu interior, através das comunicações dos padres e vigários, seja em seus adros, lugar das trocas de notícias e de convívio social, principalmente, antes e depois das missas e cerimônias religiosas) uma vez que não existiam espaços próprios para encontros demorados. Eram também dos sinos das igrejas que vinham os sons que marcavam as horas na cidade, como já havíamos dito, e todos os principais avisos de incêndios (comuns àquela época), nascimentos e mortes (Fridman, 1999).

Quanto à oferta de água, sabe-se que os habitantes banhavam-se nas lagoas e rios ou em barris, dentro de suas casas, com a água vendida por índios livres ou trazida dos poços, como os da Misericórdia e do Carmo. Os escravos lavavam-se na lagoa da Pavuna no bairro longíquo conhecido como Pedreiras. A solução encontrada pelas autoridades para o problema do saneamento foi aterrar as valas com terra retirada dos morros, o que, não raro, ocasionava a devastação das florestas.

Quanto à arte, nos séculos XVI e XVII era eminentemente sacra. Em 1638 os jesuítas iniciaram o curso de arte no Rio de Janeiro e peças artísticas como estátuas e retábulos eram elaboradas por mulatos nos domínios (rurais e urbanos), desta ordem. As representações teatrais ocorriam nos adros das igrejas e, nos autos, se os atores fossem estudantes dos loyolistas anjos e demônios dialogavam na língua tupi. No adro da Misericórdia havia dança de indiozinhos (Cruls, 1965) e consta que em 1584 foi encenado o auto "Pregação Universal" de José de Anchieta (Macedo, 1945). Acrescente-se a isto as liturgias, muitas vezes teatrais, baseadas na vida de santos. Quanto ao lazer, no século XVI ocorriam as cavalhadas, 
folguedos populares muito apreciados além das procissões, noturnas e "com acentuado sabor profano" (Coaracy, 1988: 102).

Com relação ao ensino, no século XVII os beneditinos já lecionavam filosofia e teologia no Rio de Janeiro. O Colégio dos jesuítas, de fundação real e gratuito, constituiu-se, para Lacombe (1970), na base da cultura colonial até o século XVIII. Era o centro de formação não apenas clerical - os padres foram também os primeiros professores de música no Brasil. Em 1650 foi inaugurado o estudo das artes e da teologia no Convento de Santo Antônio, dos franciscanos. Nos dois primeiros séculos a medicina coube aos padres da Companhia de Jesus, que além de utilizarem seus conhecimentos trazidos da Europa, ambientaram-se na cultura indígena. Eram médicos da população, de armadas portuguesas e do governador. No século XVII já se assinalava a presença de médicos cariocas formados pela Universidade de Coimbra, contratados para o hospital da Misericórdia. No Colégio da Companhia havia locais destinados aos enfermos, mas o primeiro hospital foi efetivamente o da Misericórdia que permaneceu o único até o século XVIII.

O crescimento do poder ideológico e econômico das ordens religiosas no Brasil na primeira metade dos setecentos (Hoonaert, 1982) pode ser atestado com fatos ocorridos na cidade do Rio de Janeiro no período. A Coroa portuguesa repassou grandes parcelas de terra aos eclesiásticos, assim como a particulares e às autoridades locais. A relação visceral com o poder pode ser constatada, quando da invasão francesa, pela presença do governador, em 1711, em terras dos jesuítas no Engenho Novo e os vereadores e nobres nas terras de Inhaúma. Este tipo de vinculação também era partilhada pelos religiosos de São Bento, do Carmo e irmãos da Misericórdia que contribuíram para o resgate da cidade. Foi quando o governador Francisco Moraes "se excedeu" na distribuição de sesmarias em terras da Câmara a particulares (Ferreira, 1976) e no parcelamento do bem público. O poderio religioso pode ser percebido também pela concessão de novos privilégios e monopólios. Em 1738, coube à Santa Casa a cobrança de um imposto sobre as embarcações atracadas no porto em troca da assistência médica aos marinheiros e a ampliação do distrito das miuças até Minas Gerais. Em 1739, a instituição obteve o direito de assistência aos menores, sobretudo os filhos de mães solteiras abastadas deixados na roda. Foram constituídos para esta finalidade a casa dos Expostos e o Recolhimento dos Orfãos (autorizado pelo Alvará de 9 de janeiro de 1695), em troca de uma contribuição que, em 1778 chegou a 800 mil réis anuais. Desde o Alvará de 9 de janeiro de 1695 os irmãos da Misericórdia foram autorizados a cuidar dos meninos de rua. A irmandade da Caridade constituída, em 1738, pelos membros da confraria do Santíssimo 
Sacramento da freguesia da Candelária, tinha como finalidades a instrução à infância desvalida e assistência aos enfermos pobres. Os irmãos prestavam socorro e sua remuneração, muitas vêzes perdoada aos mais necessitados, era doada às órfãs pobres da localidade. A Santa Casa sepultava os doentes falecidos.

De uma forma resumida, podemos afirmar que, nos serviços cotidianos que afetavam a vida da população, as ordens religiosas e as confrarias foram responsáveis pela educação (em 1735 foi constituída na igreja de São Pedro uma escola para meninos órfãos transformada no Seminário dos Orfãos de São Pedro quatro anos depois, e em 1751 foi fundado o colégio dos carmelitas), pela saúde (em 1733 foi criado o hospital da Venerável Ordem Terceira de Nossa Senhora do Monte do Carmo e, no decorrer da década de 40, aquele pertencente à Venerável Ordem Terceira da Penitência), pela hospedagem (nos hospícios), pela proteção aos fugitivos (que não podiam ser presos nos adros das igrejas) e às prostitutas. O Recolhimento de Nossa Senhora do Parto "para mulheres não virgens (...) que deixando a perversidade do século, reformaram a vida e costumes antigos, trocando-os por santa e regular conduta" (Pizarro, 1945, vol.6: 214) foi concluído em 1742 na igreja do mesmo nome. Até fins do século XVIII a cidade era iluminada pelos lampadários em frente aos edifícios religiosos ou aos nichos e oratórios nas esquinas das ruas. Esses nichos eram construídos pelos proprietários mais ilustres das ruas e os custos de sua iluminação ficavam a cargo da vizinhança que dividia as despesas, ou do nobre morador. A comunicação, aspecto importante para o dia-a-dia da cidade, envolvia igrejas e capelas, que se tornaram locais de busca de notícias, tanto para os ricos quanto para os pobres. Como já foi citado anteriormente, os sinos assinalavam eventos como os nascimentos, mortes e incêndios, muito comuns àquela época. Havia o pau da bandeira no morro do Castelo, que avisava da chegada de navios no porto. O Santo Ofício, que julgava aqueles denunciados pela Inquisição, funcionou na rua de São Pedro em casas pertencentes à irmandade do Santíssimo Sacramento da freguesia da Candelária.

Devemos considerar também o papel desempenhado pelas irmandades. Inicialmente, e seguindo uma tradição portuguesa, o congraçamento em irmandades era apenas permitido à população branca. Irmandades como a do Santíssimo Sacramento (a primeira do Rio de Janeiro), da Misericórdia, da Candelária, de São José e da Santa Cruz dos Militares tiveram suas igrejas construídas nas primeiras décadas da cidade (1568, 1582, 1607, 1608 e 1628, respectivamente). Reafirmamos que as associações religiosas leigas se constituíram em um lugar privilegiado para o encontro humano e eram, assim, instrumento de sociabilidade na colônia. 
Aos negros, excluídos do convívio social, foi inicialmente negado o direito de instituírem irmandades para si. No entanto, a partir de um determinado momento, os traços marcantes da cultura africana mantidos aqui pelos escravos de diferentes etnias, começou a ser visto como uma ameaça aos ideais portugueses. Assim, a permissão para que houvesse irmandades específicas para negros decorreu da vontade da Coroa de as impor como instrumento de socialização dos escravos nos preceitos cristãos, mesmo diante da resistência de alguns setores da elite que acreditavam não ser o negro capaz de absorver ensinamentos. ${ }^{5}$ Silva (1994) reafirma que as autoridades religiosas, de uma forma geral, apoiavam-nas como uma tentativa de integrar e cooptar os negros à sociedade portuguesa.

Mesmo com a autorização, não foi de imediato que os negros ganharam datas de terras para erguerem templos próprios. Para garantir a devoção aos santos católicos, por parte da população escrava, foi estabelecido que eles apenas teriam direito a ocupar altares já existentes nos templos das irmandades dos brancos. Assim, quando das cerimônias que exigiam a presença de todos os fiéis na igreja, os componentes das irmandades eram separados por cor e condição social. No mais, elas eram utilizadas inclusive com rodízio de horários, mesmo "a igreja tendo altares destinados a essa ou a outra cor; o negro e o pardo ocupando os altares laterais" (Méro, 1983: 23). Com o tempo e com os problemas desta convivência forçada, os negros foram construindo suas próprias capelas, quase sempre em terrenos doados pela Câmara em lugares mais distantes. As irmandades dos mais pobres e negros como as de Nossa Senhora da Lampadosa, Nossa Senhora do Rosário dos Homens Pretos, São Elesbão e Santa Efigênia e a de Nossa Senhora da Imaculada Conceição, construíram suas ermidas em locais longíquos, em áreas não consolidadas e desassistidas de equipamentos coletivos.

Generalizada a associação em irmandades, as autoridades portuguesas só não puderam evitar que os negros continuassem, apesar da escravidão, a manifestar suas crenças e sua cultura no sistema social religioso dominante. $\mathrm{O}$ sincretismo foi o resultado decorrente deste processo que fez com que nem os valores estritamente portugueses vigorassem nem os mitos africanos se mantivessem na íntegra. Um arcabouço da cultura brasileira estava evidenciado naquele momento.

\footnotetext{
5 A favor da permissão, surgiram discursos como: "Os cativos são perfeitamente capazes de saber o nome dos seus senhores, a quantidade de covas de mandioca que devem plantar num dia, quantas mãos de cana têm de cortar e outras coisas pertencentes ao serviço ordinário de seu senhor. São ainda aptos a pedir perdão quando erram, a rogar a suspensão de um castigo: por que então não haveriam de aprender a se confessar, a rezar pelas contas, a enunciar os Dez Mandamentos?”. (Souza, 1986: 93)
} 
Uma colônia escravista estava pois fadada ao sincretismo religioso. Outorgado, talvez, num primeiro momento, pela camada dominante, o sincretismo afro-católico dos escravos foi uma realidade que se fundiu com a preservação dos próprios ritos e mitos das primitivas religiões africanas. Cultuava-se São Benedito, mas cultuava-se também Ogum, e batiam atabaques nos calundus da colônia: nas estruturas sociais que lhe foram impostas, os negros, através da religião, procuraram "nichos" em que pudessem desenvolver integradamente suas manifestações religiosas. Arrancados das aldeias natais, não puderam recriar no Brasil o ambiente em que haviam se constituído suas divindades; entretanto, ancorados no sistema mítico originário, recompuseramno no novo meio. (...) A religião africana vivida pelos escravos negros no Brasil tornou-se assim diferente da de seus antepassados, mesmo porque não vinham todos os escravos de um mesmo local, não pertencendo a uma mesma cultura. Gêges, nagôs, iorubas, malês e tantos outros trouxeram cada um sua contribuição, refundindo-as à luz de necessidades e realidades novas (...). Para que pedir fecundidade às mulheres se, na terra do cativeiro, elas geravam bebês escravos? Como solicitar aos deuses boas colheitas numa agricultura que beneficiava os brancos, que se voltava para o comércio externo e não para a subsistência? Mais valia pedir-lhes a seca, as epidemias destruidoras de plantações, pois colheitas abundantes acabariam se traduzindo em mais trabalho para o escravo, mais fadiga, mais miséria. A primeira seleção operada no seio da religião africana colocaria de lado as divindades protetoras da agricultura, valorizando, em contrapartida, as da guerra (Ogum), da justiça (Xangô) e da vingança (Exu). Eivado de paganismos e de "imperfeições", conforme se viu acima, o catolicismo de origem européia continuaria, na colônia, a se mesclar com elementos estranhos a ele, multifacetados muitas vezes, como a própria religião africana transmigrada. (Souza, 1986: 93-4)

As irmandades, como instrumento de ação social da população negra, acrescentaram um toque africano ao barroco colonial brasileiro. É, neste sentido, que autores como Mira (1983) consideram o século XVIII, quando proliferaram estas instituições, como o momento determinante da constituição dos elementos negros na sociedade brasileira. Fato oposto ao que aconteceria no século seguinte, marcado neste aspecto, desde a vinda da família real portuguesa para o Rio de Janeiro até as políticas de imigrantes das últimas décadas, por uma evidenciada dominação dos valores da cultura européia, às vezes em uma evidenciada tentativa de "branqueamento" da nossa sociedade. O sincretismo marcou, pois, uma das condições dos países de escravidão que foi a mistura de raças e de povos, a coabitação das mais diversas etnias em um mesmo lugar e a criação, acima das nações centradas nelas mesmas, de uma nova forma de solidariedade, no sofrimento, uma "solidariedade de cor" (Bastide, 1989: 260)

Como instituições desenvolvidas no seio de uma sociedade estratificada social e racialmente, pode-se afirmar que, pela possibilidade de ajuda mútua, "os pobres precisavam 
mais das irmandades do que os brancos ricos" (Silva, 1994.: 125). Os serviços sociais destas instituições constituíam-se, desta forma, em suas mais importantes funções. Para os negros, que desejavam obter proteção, ter um ponto de encontro longe dos olhares dos senhores, assegurarem para si e para os seus familiares o direito a um enterramento digno e uma ajuda financeira para as suas viúvas e filhos, a união em irmandades foi decisiva para a sua sobrevivência em meio à escravidão. As irmandades, através de seus mecanismos de arrecadação, ofereciam também empréstimos aos negros que queriam comprar a sua liberdade e ainda ajudavam-nos em processos judiciais, contra seus senhores ou herdeiros, por causa da alforria. Com efeito, o compromisso da irmandade de Nossa Senhora do Rosário no início do século XVIII explicitava estas funções.

(sic) CAPITULO I: Deveres da Irmandade.

1. Prestar devoto culto á Maria Santissima do Rosario.

2. Sepultar os irmãos defuntos e suffragar suas almas.

3. Cuidar da educação dos filhos legitimos dos irmãos que morrerem em indigencia, comtanto que estes tenham pelo menos um anno de recebidos na Irmandade, promovendo a entrada daquelles nas escolas de lêr, escrever e contar, ministrando os soccorros para isso necessarios, á proporção das rendas da mesma Irmandade.

4. Libertar da escravidão aos irmãos captivos. (Biblioteca Paulo Santos, códice 255-815.3)

Outra importante função desempenhada por estas instituições foi a possibilidade de se organizarem em festas que, além de satisfazerem as necessidades religiosas da população congregada, proporcionavam divertimento e formas de expressão em uma época em que eram poucas as oportunidades de diversões para os escravos. Os temas recorrentes nas festas das irmandades negras era, além da "necessária" citação aos santos católicos, a recriação de suas províncias natais (rememorando as suas autoridades) e, muitas vezes, na medida do possível, críticas às suas condições de vida e aos seus colonizadores.

As festas promividas pelas irmandades de negros, sobretudo a do Rosário, a da Lampadosa e a de São Jorge, além de muita ostentação, sempre foram marcadas por sua musicalidade. Até no momento de seus preparativos, este caráter era observado. No caso particular da festa da Lampadosa, Schubert (1948: 53) escreve que "em dias anteriores ao Dia de Reis, saíam bandos de pretos cantando e dançando (com instrumentos de suas terras) pelas ruas da cidade, além de chácaras e fazendas do Engenho Velho e Engenho Novo do Macaco recolhendo esmolas e donativos para a festa." 
Uma das mais curiosas procissões promovidas pelos negros da Lampadosa foi a do Rei Baltazar na qual, durante os festejos, "eram eleitos imperador e imperatriz negros que recebiam dignidade de soberano" (Santos, 1990: 21). De características tipicamente africanas, evocando seus usos e costumes, com ritmos das suas províncias de origem, estes eventos conseguiam monopolizar a atenção e os esforços de todos os membros da irmandade.

Sobretudo a partir da segunda metade do século XVIII, os negros do Rosário realizavam procissões que, também retratando côrtes africanas, se destacaram no cotidiano da cidade pela grandiosidade de seu cortejo público, com música e dança simbólicas de sua cultura.

Assim como em outras festas havia um imperador, nas do Rosário havia rei e rainha com sua competente corte e cuja realeza durava um ano. O negro e a negra, rei e rainha da festa, apresentavam-se trajando riquíssimos vestidos (...) imitando o mais possível as vestes reais dos antigos tempos. (Maurício, 1966: 68)

Ou ainda:

Escravas com penas na cabeça e trazendo roupagens de muitas cores, tocavam e dançavam no acompanhamento da rainha (...) com jóias enfeitando-a, tendo na cabeça a coroa e na mão o cetro. Uma escrava sustentava o manto vermelho (...) e outra protegia a rainha com grande gaurda-sol. (Cruls, 1965: 384)

Também a irmandade de São Jorge, mesmo muito modesta, promovia suas festas pelas ruas da cidade sempre com destaque para a riqueza da vestimenta dos irmãos. A pompa com que ocorriam tais procissões, mesmo não sendo nenhuma daquelas “das del Rey”, expressava, de acordo com Scarano (1994), uma ruptura que os negros estabeleciam com sua vida diária, um momento de encontro com uma posição elevada, distinta e inatingível em seu cotidiano. Até nas festas comuns a todos os habitantes da cidade, continua a autora, os negros que delas participavam timbravam em se vestir como os demais, com o mesmo luxo e qualidade. Para os negros, o "expressar-se" através das festas era uma experiência máxima de liberdade, era um raro momento no qual, seguindo as palavras de Mira (1983: 134 apud Hoornaert, 1982), "deixava de ser um ser para o outro para ser um ser para si”.

A este ritmo, o fato foi que a população negra da cidade do Rio de Janeiro (e de todo o Brasil), na vinculação de suas crenças e costumes ao culto das santidades da Igreja Católica, acabou por sincretizá-los conforme avançou a colonização. Por conseguinte, tais "abusos" 
foram combatidos pelas elites a despeito do uso do sincretismo como controle social e ideológico.

As visitações do Santo Ofício acusaram (mais nos séculos XVI e XVII, menos na segunda metade do XVIII) imensa intolerância para com as práticas sincréticas, o mesmo acontecendo com o Tribunal de Lisboa quando, constituídos processos aqui na colônia, seguiam para serem julgados lá. Autoridades municipais bateram-se muitas vezes contra as congadas e reizados. (...) A especificidade da religião praticada na colônia (o culto dos santos, o número excessivo de capelas, o aspecto teatral da religião, o que se convencionou chamar de "exterioridade" e de "ignorância religiosa") escandalizou os viajantes estrangeiros que por aqui passaram. Diziam eles, sobretudo os anglos-saxões e protestantes, que os brasileiros de cor estavam desvirtuando o cristianismo, fazendo dele uma mistura de imoralidade e cerimônia burlescas. (Souza, 1986: 99-100)

Conta-se, inclusive, que boa parte da população branca da cidade chegou a desenvolver um medo em relação às comemorações dos negros, trancando-se em suas casas ao menor sinal de seus batuques, desprezando-as também por considerá-las um desacato e uma carnavalização da religiosidade cotidiana.

Além das festas, que serviam de instrumento de afirmação dos negros na sociedade, as irmandades também se traduziam na oportunidade que tinham para obter um enterramento digno. Em um contexto em que, tratados como "peças", eram simplesmente abandonados em qualquer local ermo quando falecidos, a garantia de um sepultamento em chãos da irmandade representou uma grande conquista social. Novamente, as cerimônias preparadas por estas instituições eram marcadas pelo sincretismo, mantendo-se, inclusive, as honras para os mortos de alta descendência africana. Com efeito,

As superstições continuam a florescer na nossa capital fluminense (...) como quando se dava em cheio com um ruidoso funeral de filho de rei africano (o qual continuara na escravidão a exercer prestígio e autoridade sobre os ex-vassalos de seu pai), cujo cadáver fôra velado por deputações das diferentes nações da Costa, e se transportava numa rede, precedida de um negro atirando foguetes e bombas e de outros executando em todo o percurso cabriolas pelo chão, e seguida de uma multidão cor de ébano, em parte silenciosa, lúgubre e burlesca a um tempo, em parte tangendo instrumentos esquisitos e entoando cantigas estridentes. (Lima, 1996: 593)

Irmandades como a do Rosário e a da Lampadosa foram as que primeiro possuíram cemitérios no Rio de Janeiro. Se a população branca tinha sepultamento garantido em suas 
igrejas ou no terreno da Misericórdia, a partir de então estava igualmente providenciado aos demais este direito, mesmo com as constantes dificuldades em custeá-lo.

Se de todo era destituída de bens a gente do morto, o corpo expunha-se na rua dentro da rede mortuária, a fim de recolher os óbulos dos viandantes que permitissem a imunação, a qual sempre custava alguma coisa. Não havia risco de ficar um cadáver insepulto, porque a caridade dos negros se manifestava infalivelmente para com os falecidos irmãos desvalidos. (Lima, 1996: 594)

Um outro caráter das irmandades de negros que possibilita considerá-las como mecanismos de ação social faz referência ao fato de que muitos escravos, através delas, conseguiram a liberdade. $\mathrm{Na}$ ocasião das grandes festas comemorativas a quantia recolhida dos congregados ou doadas por terceiros servia para a compra da alforria de irmãos de acordo com sorteios ou, segundo Cruls (1965), obedecendo a hierarquia social proveniente de suas terras de origem.

\section{Considerações finais}

A chegada dos religiosos no Brasil coincidiu com o advento da Contra-Reforma, quando a Igreja Católica redefiniu seu papel. Neste contexto, as ordens e confrarias além de dominarem os principais setores econômicos, estenderam sua supremacia à produção do saber e à cultura em geral, isto é, estiveram à frente da hegemonia ideológica. Tal influência se expressou pela dominação territorial e por esse motivo deve-se falar em geopolítica colonial.

Como a propriedade fundiária determinava a forma e o uso do solo, o espaço do Rio de Janeiro não era uniforme. Os locais e ruas da cidade eram, muitas vezes, especializados por funções e segregados pelas ordens e confrarias que representavam as classes de renda. Pudemos verificar no texto que tal segregação, resultado do valor de uso e não do preço, decorria da distribuição arbitrária. O binômio valorização/segregação diz das características urbanas anteriores ao sistema capitalista de produção.

No período colonial - incluídas aí heranças feudais, quando a terra foi doada em troca do pagamento do fôro - cada ordem ou confraria dominou uma parcela diferenciada do território. No campo da relação Igreja/Estado e na falta de normas civis específicas para a conformação urbana, as leis eclesiásticas tornaram-se definidoras do estabelecimento das atividades e dos caminhos da expansão territorial. O clero impôs normas expressas para os assentamentos dos edifícios e das propriedades sagradas. O uso do solo carioca mostrou, 
portanto, um jogo de forças que teve expressão jurídica e política. Portanto, a distribuição espacial e social dos agentes e dos equipamentos coletivos incidiu diretamente sobre o cotidiano da população.

O papel indutor das grandes ordens religiosas se evidencia quando percebemos que foram elas os agentes que abriram ruas, dominavam parcelas do território urbano e rural, serviam como fatores de valorização das terras, direcionavam vetores de expansão da cidade na medida em que abriram caminhos às suas fazendas e mais uma série de outras determinações que exerciam como conseqüência de suas atribuições sociais e ideológicas.

No caso particular da cidade do Rio de Janeiro, os religiosos, de uma forma geral, podem ser apontados como fortes impulsionadores da política de conformação do "chão" carioca na medida em que a maioria dos estabelecimentos sob a jurisdição ou a cargo das ordens acabaram por se transformar em distritos, bairros ou pontos de referência da cidade, com significativa presença em sua toponímia.

Sobre a importância e significado do papel desempenhado pelas irmandades religiosas negras para o processo de conformação espacial da cidade do Rio de Janeiro, pelo menos três importantes constatações podem ser feitas: 1) As irmandades foram, para os leigos da cidade e da colônia, locus de expressão religiosa e, sobretudo, para os negros, instrumento de reivindicações e de afirmação social; 2) Representaram um mecanismo pelo qual o espaço da cidade, que se estruturava internamente e iniciava sua expansão, foi ocupado de modo diferenciado pelos diversos agentes da época, como consequência das práticas sociais nela mantidas; e 3) Foram reflexo e condição da divisão social e racial existente na sociedade a ponto de permitir irmandades para brancos, negros, pardos e mulatos, que não se assimilavam.

E por fim, a partir da distribuição geográfica dos marcos edificados na cidade e de sua dinâmica social, podemos nos reportar ao período colonial brasileiro, usando conceitos consagrados posteriormente, para considerarmos as irmandades religiosas em questão como "agentes modeladores" do espaço urbano carioca com funções de "agentes imobiliários". Senão, podemos considerá-las agentes comprovadamente responsáveis por determinadas aglomerações e/ou adensamento, parcelas privadas do solo convertidas em arranjos territoriais e de controle, que acabaram por desenhar formas ainda atuais.

Pode-se considerar as ordens religiosas e confrarias como agentes modeladores do espaço urbano no período colonial com funções de agentes imobiliários. Além da tipologia das edificações, a cidade colonial já apresentava uma paisagem marcada pela ocupação 
diferenciada do solo. Esta afirmação pode ainda ser melhor compreendida ao lembrarmos que o Rio de Janeiro surgiu e se desenvolveu sem planejamento possibilitando, assim, um processo (aparentemente) espontâneo de expansão urbana, segundo interesses locais. A ocupação simultânea de vários espaços na cidade era, no entanto, realizada de forma diferenciada pelos diversos agentes. Com a Lei de Terras de 1850, que marcou o início da mercantilização do chão devoluto, novos agentes produtores do espaço urbano carioca se constituíram e, naquele instante, se rompeu o monopólio imobiliário religioso.

\section{Referências bibliográficas}

Avelar, H. A. Organização e vida político-administrativa e eclesiástica, in RIHGB (288), jul/set. 1970.

Bastide, R. As religiões africanas no Brasil. Contribuição a uma sociologia das interpretações de civilizações. São Paulo: Pioneira, 1989.

Boxer, C. R. O império marítimo português (1415-1825). Lisboa: Edições 70, 1992

Coaracy, V. Memórias da cidade do Rio de Janeiro. Belo Horizonte/São Paulo: Itatiaia/EdUSP, 1988.

Costa, J. J. Breve notícia da irmandade de Nossa Senhora do Rosário e São Benedito dos Homens Pretos do Rio Capital do Império do Brasil. Rio de Janeiro; Typ. Poytechnica, 1886.

Cruls, G. Aparência do Rio de Janeiro. Rio de Janeiro: Livraria José Olympio Editora, 1965, 2 vols.

Cunha, L. A. Aspectos sociais da aprendizagem de ofícios manufatureiros no Brasil colônia, in Fórum 2 (4), out/dez 1978.

Facó, A. D. (coord.) Guia das igrejas históricas da cidade do Rio de Janeiro. Rio de Janeiro: Prefeitura Municipal/IplanRio/Noberto Odebrecht S.A., 1997.

Ferreira, J.C. A cidade do Rio de Janeiro e seu termo. Rio de Janeiro: Prefeitura da Cidade do Rio de Janeiro, 1976.

Fridman, F. Donos do Rio em nome do rei; uma história fundiária da cidade do Rio de Janeiro. Rio de Janeiro: Garamond/Jorge Zahar Editor, 1999.

Fridman, F.; Macedo, V. L. Irmandades de negros: desterro no Rio de Janeiro colonial. In: Anais do Seminário Nacional "Diáspora negra: uma contribuição à arquitetura e à organização do espaço no Brasil”. Salvador, UFBA/FAU, 1997.

Hoornaert, E. A Igreja no Brasil Colônia. São Paulo: Brasiliense, 1982.

Lacombe, L. L. Ordens religiosas, irmandades e confrarias, in RIHGB (288), jul/set. 1970.

Lima, O. Dom João VI no Brasil. Rio de Janeiro: TopBooks, 1996, $3^{\mathrm{a}}$ ed.

Macedo, S. D. T. Rio de Janeiro, guia turístico, histórico, sentimental da cidade mais bonita do mundo. Rio de Janeiro: s.n.t., 1945.

Marx, M. Cidade no Brasil, terra de quem? São Paulo: Nobel/EDUSP, $1991 .$.

Maurício, A. Algo do meu velho Rio. Rio de Janeiro: Brasiliana, 1966.

Méro, E. Discriminação racial nas irmandades. Maceió: UFAL, 1983.

Mira, J. M. L. A evangelização do negro no período colonial brasileiro. São Paulo: Loyola, 1983 
Pizarro e Araújo, J. S. A. Memórias históricas do Rio de Janeiro. Rio de Janeiro: Imprensa Nacional, 1945, 11 vols.

Santos, J. G. Igreja de Nossa Senhora da Lampadosa; dos pretos-minas aos portugueses. Rio de Janeiro: UERJ/IFCH, monografia de Graduação, mimeo, 1990.

Scarano, J. Cotidiano e solidariedade; vida diária da gente de cor nas Minas Gerais do século XVIII. São Paulo: Brasiliense, 1994.

Schubert, G. A província eclesiástica do Rio de Janeiro. Rio de Janeiro, Agir, 1948.

Silva, M. B. N. Dicionário da colonização portuguesa no Brasil. Lisboa: Ed. Verbo, 1994.

Silva Telles, M. L. A conquista da terra e a conquista das almas. In: A forma e a imagem; arte e arquitetura jesuítica no Rio de Janeiro colonial. Rio de Janeiro: Ed. PUC, 1992.

Souza, L. M. O diabo e a terra de Santa Cruz; feitiçaria e religiosidade popular no Brasil Colonial. São Paulo: Companhia das Letras, 1986

Torres, J. C. O. História das idéias religiosas no Brasil, São Paulo: Ed. Grijalbo, 1968.

Vieira Fazenda, J. Antiqualhas e Memórias do Rio de Janeiro, in RIHGB (140) 1921, (142) 1923.

Fontes primárias

Biblioteca Nacional: documentos diversos sobre o Brasil colonial e sobre as irmandades.

Códice 040 L732.5s: Compromisso da Irmandade de Nossa Senhora do Amparo ereta na matriz do Patriarca São José desta Corte e cidade do Rio de Janeiro, 1839.

Biblioteca Paulo Santos: livros de compromissos e de reuniões das mesas administrativas das irmandades.

Códice 255 (815.3) Irm: Compromisso da Irmandade de Nossa Senhora do Rosário, 1928.

Instituto do Patrimônio Histórico e Artístico Nacional (IPHAN): pastas de inventários de bens tombados na cidade do Rio de Janeiro.

Pasta: Igreja do Rosário e São Benedito. 